has been appointed head of the Department of Research in Physical Chemistry, has distinguished himself in applied mathematics, particularly as employed in the analysis of chemical engineering problems, and in petroleum chemistry, especially in his comprehensive original work on distillation. $\mathrm{He}$ was born in New York, in 1910, and educated at the University of Pittsburgh and at the California Institute of Technology. Since 1935 he has been at the Mellon Institute, on the multiple fellowship of the Gulf Research and Development Co.

\section{Public Libraries in Germany}

H. SchURER's paper "Public Libraries in Germany", published as No. 5 in the German Educational Reconstruction Series (15 James Street, London, W.C.2), gives a readable account of the development of the public library system in Germany and of the two schools of thought, neither favouring open access to the shelves, which influenced. that development down to the Nazi regime; it also deals with the part which the system could play in the educational reconstruction of Germany. The ideas of Walter Hofmann and his school in making book selection the decisive intellectual task of library service, with all its implied demands on the library staff, are set forth in some detail and should be of considerable interest to those engaged in library work in Britain, whether in the public library service, in the universities or in industry and commerce. The special characteristics of the tradition of German librarianship are of international significance, and a chapter in L. R. Wilson and M. F. Tauber's book on the university library suggests that that tradition has already made its influence felt in the United States as a positive contribution in library service. As regards the immediate future in Germany, apart from the restoration of damaged buildings and the recovery of lost stocks, Mr. Schurer considers that the main task will be the negative one of undoing most of the work of the Nazis, including the elimination of Nazi literature from book collections, removal of ardent Nazis from responsible positions, the preparation of new readers' guides and the training of library workers. Furthermore, he considers that the principle of open access must now be adopted, and he looks to a steady increase in the number of readers and to a healthy development of local and regional efforts rather than national or centralized efforts.

\section{Glasgow Art Gallery and Museum}

COMMENDABLE enterprise in making the natural history department attractive to visitors has been shown recently by the Glasgow Art Gallery and Museum. Despite special difficulties caused by enemy action during the War, considerable material has been salvaged and displayed as a series of habitat groups in an Animal Court at the Museum. The first and second arches contain representative samples of African and Indian animals, and the others in preparation will display animals of Australia and the Scottish Highlands. To accompany each display the Museum is publishing a series of attractive booklets in which each animal typified is described and illustrated. "Animals of Africa" and "Animals of India" are already available.

\section{Medical Sub-Section of the Library Association}

THE first ordinary meeting of the newly formed Medical Sub-Section of the Library Association was held at the National Institute for Medical Research on January 2. In welcoming the seventy or more members and guests, Dr. C. R. Harington, director of the Institute, spoke of the increasingly important part played by library services in the modern medical world and of the invaluable aid that specially trained librarians could give to those engaged in medical practice and research. Dr. G. Popjak gave an illuminating talk on recent developments in nuclear physics and their medical applications ; his exposition of the manufacture of radioactive isotopes was much appreciated. Miss Ethel Wigmore, librarian to the Medical Research Council and a member of the Committee of the Medical Sub-Section, then described the work of the Library of the Institute, and this was followed by a conducted tour. The members were especially interested in the system of indexing current periodical literature pending the issue of the Quarterly Cumulative Index Medicus, and in the very comprehensive subject-index to the large collection of reprints.

\section{Institution of Electrical Engineers: Awards}

THE triennial award of the Coopers Hill War Memorial Prize and Medal, which fell in 1946 to the Institution of Electrical Engineers, has been made by the Council to Mr. E. C. Cherry, for his paper on "Analogies between the Vibration of Elastic Membranes and Electro-Magnetic Fields in Guides and Cavities".

No award having been made in 1946 of the Page Prize for the best thesis in lieu of the Associate Membership Examination of the Institution, the Council has awarded two Page Prizes for 1947 : one to Mr. D. T. Hollingsworth for his thesis entitled "An Account of the Development of the Accessories for a Cable with the Dielectric under Pressure"; and the other to Mr. M. K. Taylor for his thesis entitled "The Transmission of Voice Frequencies by Height Modulated Pulses of Constant Recurrence".

\section{Announcements}

Applications are invited for research fellowships, normally of the value of $£ 600$ per annum, founded by Imperial Chemical Industries, Ltd., tenable in the University of Cambridge and available for research in physics, chemistry, biochemistry, engineering, metallurgy, pharmacology, chemotherapy, or related subjects. Applications should be received not later than April 30. Regulations governing the award of the Fellowships may be obtained from the Secretary of the Board of Research Studies, The Old Schools, Cambridge, to whom all applications should be addressed.

A PRELIMINARY announcement under the title "Photostat Copies of German Scientific and Technical Papers" appeared in Nature of September 27, 1947, p. 427. It has now proved possible to reduce the cost of this service and a revised charge of $6 d$. per page, irrespective of number, is now being made.

ErratuM.-Mr. A. B. Wardrop and Dr. R. D. Preston write : "In our recent article entitled "Organisation of the Cell Walls of Tracheids and Wood Fibres" in Nature of December 27, p. 911, we inadvertently allowed the same mistake to occur in three places. The legends to the abscissæ of Figs. 3 and 4 should read 'Angle of section to transverse plane' and the word 'increasing' (p. 912, line 8) should read 'decreasing'." 